\title{
Spinal tuberculosis and tuberculous psoas abscess
}

\author{
Charles Hamish Coughlan, ${ }^{1}$ Josephine Priest, ${ }^{1}$ Akkib Rafique, ${ }^{2}$ William Lynn ${ }^{1}$
}

${ }^{1}$ Ealing Hospital, London North West University Healthcare NHS Trust, Southall, UK

2Department of Radiology, Ealing Hospital, London North West University Healthcare NHS Trust, Southall, UK

\section{Correspondence to} Dr Charles Hamish Coughlan; charles.coughlan@nhs.net

Accepted 3 December 2019

\section{DESCRIPTION}

A 45-year-old Indian labourer presented to his general practitioner with chronic low back pain. This had worsened over 4 months and radiated to the left thigh. He denied urinary and faecal incontinence, leg weakness, numbness and paraesthesia. There was no significant past medical history. His general practitioner suspected musculoskeletal injury and arranged a lumbar X-ray to exclude bony abnormalities.

Plain lumbar X-ray showed loss of intervertebral disc space at T12-L1, and an enlarged left psoas shadow (figure 1), appearances concerning for discitis, vertebral collapse and psoas abscess formation. Further imaging was arranged given the patient's ethnic origin and the high prevalence of tuberculosis (TB) around our urban district general hospital. Chest radiograph showed right middle zone consolidation and pleural effusion. He was urgently referred to our infectious diseases team.

On further questioning, he denied fever, cough, breathlessness and night sweats, but recalled a $4 \mathrm{~kg}$ weight loss in the past month. He had emigrated to the UK from India 2 years previously and had not travelled abroad since his arrival. He had no known past contact with TB.

Examination revealed reduced air entry at the right base and tenderness over the L1 vertebra. There was no limb weakness, numbness, reduction in anal

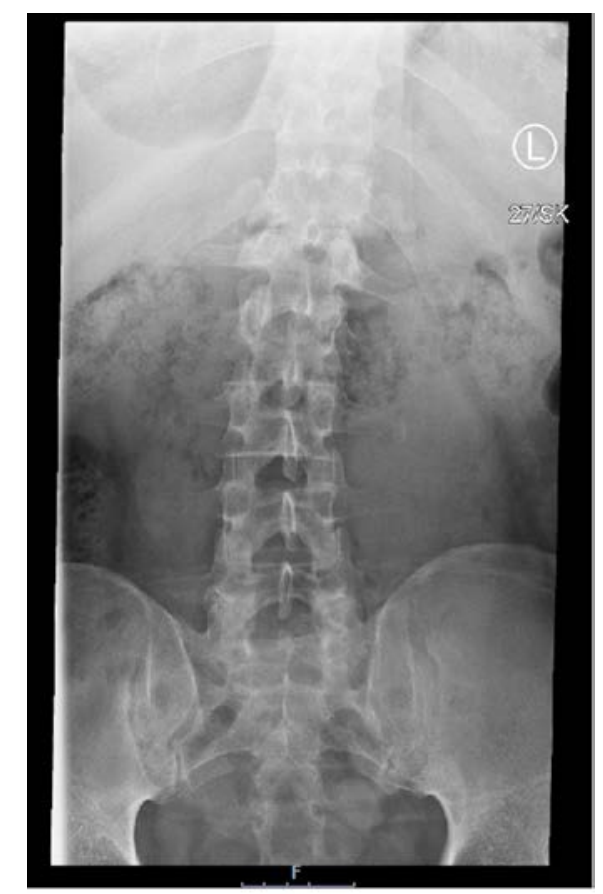

Figure 1 Lumbar spine X-ray demonstrating loss of disc space at T12-L1 and an enlarged left psoas shadow.

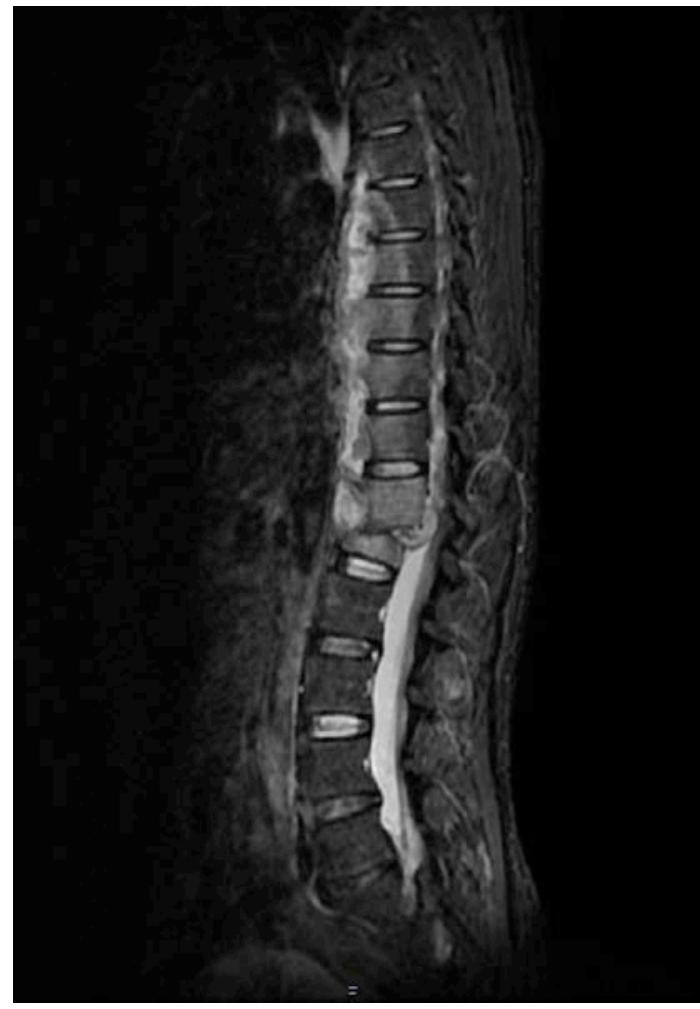

Figure 2 Short T1 inversion recovery MR sagittal section demonstrating paravertebral and large extradural abscesses.

tone or palpable abdominal masses. Temperature was $37.8{ }^{\circ} \mathrm{C}$. Blood tests showed mild normocytic anaemia, raised inflammatory markers (C-reactive protein 42) and normal white cell count. HIV and hepatitis $\mathrm{B}$ and $\mathrm{C}$ serology were negative, and random glucose was measured at $6 \mathrm{mmol} / \mathrm{L}$.

Computed tomography (CT) imaging of the abdomen and pelvis confirmed loss of height and end plate destruction of the T12-L1 vertebral bodies, and identified a large, loculated psoas abscess measuring $75 \times 52 \times 120 \mathrm{~mm}$. Purulent fluid $(300 \mathrm{~mL})$ was aspirated after ultrasoundguided percutaneous drain insertion. Acid fast bacilli were seen on drain fluid microscopy, and GeneXpert testing was positive for Mycobacterium tuberculosis with no rifampicin resistance. He was started on analgesia, antituberculous therapy and dexamethasone.

Magnetic resonance (MR) imaging of the spine demonstrated a large paravertebral abscess extending from T6 to L1, and an extradural abscess causing mild cord compression (figure 2). He was fitted with a spinal brace on the advice of the neurosurgical team. Repeat ultrasound imaging confirmed resolution of his psoas abscess and he 
was discharged home with analgesia, antituberculous therapy and a weaning steroid regimen. Interval MR scan at 9 months showed a reduction in the size of the collection at T12-L1. He completed a 12 month course of treatment and has returned to work.

This immunocompetent patient presented with vague low back pain, illustrating the diagnostic challenge posed by spinal TB. A total of 147 cases of spinal TB were recorded in England in 2018, representing 3.2\% of cases. ${ }^{1}$ Despite extensive disease, our patient was afebrile and continued to walk unaided at the time of diagnosis. Mycobacterial psoas abscesses are uncommon, usually resulting from contiguous spread from spinal TB. ${ }^{1}$

\section{Learning points}

- Spinal tuberculosis (TB) is an important differential diagnosis for back pain, particularly in young and middle aged adults hailing from hyperendemic settings.

- Psoas abscess is a rare manifestation of extrapulmonary TB, usually resulting from contiguous spread from a spinal source.

- Spinal column stability is an important consideration in patients with spinal TB.
Although CT imaging is sensitive in identifying psoas abscesses, ${ }^{2}$ MR imaging is the preferred modality in patients with spinal involvement to inform the need for neurosurgical intervention. ${ }^{3}$

Contributors $\mathrm{CHC}$ conceived the article and obtained the patient's written consent. CHC and JP wrote the first draft. AR performed image guided percutaneous drainage of the patient's psoas abscess and sourced high quality images for this report. WL and AR critically reviewed the manuscript for accuracy and intellectual content. All authors revised subsequent drafts and approved the final version of the article.

Funding The authors have not declared a specific grant for this research from any funding agency in the public, commercial or not-for-profit sectors.

Competing interests None declared.

Patient consent for publication Obtained.

Provenance and peer review Not commissioned; externally peer reviewed.

\section{REFERENCES}

1 Public Health England Tuberculosis Unit. Tuberculosis in England: 2019 report. public health England, 2019. Available: https://assets.publishing.service.gov.uk/government/ uploads/system/uploads/attachment_data/file/821334/Tuberculosis_in_Englandannual_report_2019.pdf [Accessed 18 Nov 2019].

2 Mallick IH, Thoufeeq MH, Rajendran TP. Iliopsoas abscesses. Postgrad Med J 2004;80:459-62.

3 Sinan T, Al-Khawari H, Ismail M, et al. Spinal tuberculosis: CT and MRI feature. Ann Saudi Med 2004;24:437-41.

Copyright 2019 BMJ Publishing Group. All rights reserved. For permission to reuse any of this content visit https://www.bmj.com/company/products-services/rights-and-licensing/permissions/

BMJ Case Report Fellows may re-use this article for personal use and teaching without any further permission.

Become a Fellow of BMJ Case Reports today and you can:

- Submit as many cases as you like

- Enjoy fast sympathetic peer review and rapid publication of accepted articles

- Access all the published articles

Re-use any of the published material for personal use and teaching without further permission

Customer Service

If you have any further queries about your subscription, please contact our customer services team on +44 (0) 2071111105 or via email at support@bmj.com.

Visit casereports.bmj.com for more articles like this and to become a Fellow 